World Applied Sciences Journal 11 (9): 1077-1088, 2010

ISSN 1818-4952

(C) IDOSI Publications, 2010

\title{
Life Cycle Impact Assessment (LCIA) Using the Ecological Scarcity (Ecopoints) Method: A Potential Impact Analysis to Potable Water Production
}

\author{
${ }^{1}$ Amir Hamzah Sharaai, ${ }^{2}$ Noor Zalina Mahmood and ${ }^{2}$ Abdul Halim Sulaiman \\ ${ }^{1}$ Institute of Teacher Education, Tuanku Bainun Campus, 14000 Bukit Mertajam, Penang \\ ${ }^{2}$ Institute of Biological Sciences, Faculty of Science, University of Malaya, 50603 Kuala Lumpur
}

\begin{abstract}
Life cycle assessment (LCA) is a method to analyze a product or service from the beginning of the process where it is extracted until it is not useful anymore or it is known as cradle-to-grave analysis. LCA analysis includes the inventory collecting all types of emission and waste. After this is done, the inventory will be interpreted to the environmental impacts in Life cycle impact assessment (LCIA). Two LCIA methods identified are Midpoint and Endpoint approaches. The Ecological Scarcity (Ecopoints) is an LCIA method using Midpoint approach. From the analysis to both life cycle stages analysis for potable water production which are construction stage and production stage indicate that both stages contribute two main impacts namely NOx dan SOx. In production stage, NOx and SOx were released from PAC production. On the other hand for the construction stage, NOx and SOx were released from steel production process.
\end{abstract}

Key words:Ecopoints method, LCIA - Potable water production - Midpoint approach - Poly Aluminium Chloride (PAC) and steel production

\section{INTRODUCTION}

Impact assessment is used to identify significant potential environmental effect by using the results of life cycle impact analysis (LCI). LCIA is very different from other techniques such as environment impact assessment (EIA) and risk assessment because the approach uses functional unit. LCIA comprises four elements namely the classification, characterization, normalization and weighting but normalization and weighting are the optional element [1]. According to [2], the classification of LCI due to the impact categories is through the impact pathway which begins from LCI results until the endpoint. The explanation on impact pathway is also touched in ISO [2] where:

'LCI results are classified into the impact categories and category indicators that can be stated in any LCI results (mid) with the end-point category'.

In accordance with the above explanation, two approaches are developed to explain the inter-connection of the LCI results with the environmental impacts via mid-points or end-points approaches [3-8]. According to [9], the main different between both models is the methodology how category indicators are presented to translate the achieved impact categories.
Figure 1. Explain about the impact pathway begin from LCI results until the end-point. The emission of ozone depletion gasses is used as an example for the characterization of ozone depletion gasses that can be conducted either until mid-point or end-point. Impact in mid-point is the ozone layer depletion and impact in the end-point is the protected area involving human health, natural biotic environment and manmade environment.

Midpoint Approach: The LCIA mid-point approach also known as problem-oriented approach $[6,10]$ or classical impact assessment method [2,5]. The term mid-point refers to the category indicator for each impact category which is expressed in the mid pathway of impact between LCI results and end-point [11]. Mid-point translates the category impact into real phenomenon as such as climate change, acidification and aquatic toxicity [7]. Example of methodology that was developed using the midpoint approach is CML 2001 [3, 10], EDIP 97 and TRACI [11].

Endpoint Approach: The end-point LCIA methodology is also known as damage-oriented approach [10]. End-point approach according to [3] are the elements inside the impact pathway that consists of independent value for society. The term 'end-point' is refers to the category

Corresponding Author: Amir Hamzah Sharaai, Institute of Teacher Education, Tuanku Bainun Campus, 14000 Bukit Mertajam, Penang E-mail: amirhamzah5@yahoo.com. 


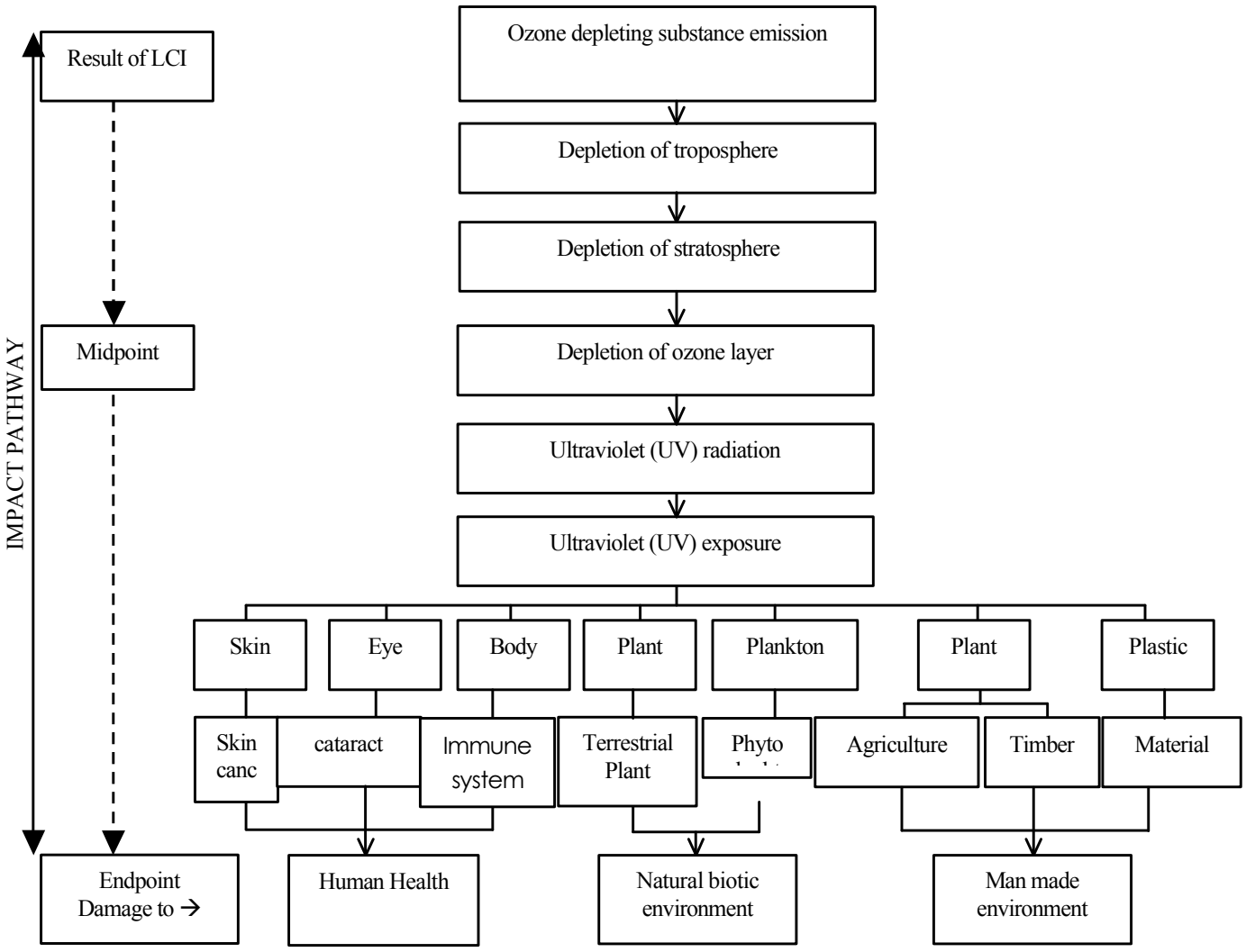

Fig. 1: Impact pathway connecting the emission to several deterioration categories

indicator for each impact category located at the end of impact pathway as in the Figure 1. End-point indicator translates the category impact based on the area of protection such as human health, natural environmental quality, natural resources and human made environment [12]. Example of end-point methodology are Eco-indicator 95 and 99, EPS 92, 96 and 2000 and LIME 2003 [13].

According to Reap et al. [14], there are several factors affecting the level of confidence and suitability of LCA research result which include option of LCIA methodology either using the mid-point or end-point approach. Reap et al. mentioned, end-point impact category is less comprehensive and posses higher level of uncertainty compared to mid-point impact category. Nevertheless mid-point impact category is difficult to be interpreted especially in the process of decision making because the mid-point impact category is not directly correlated with the area of protection (i.e. damage to human health, ecosystem quality and resource depletion) which is practiced by the end-point.

Methodology of LCA: There are four main phases in LCA as suggested in ISO 14040 series:

2.1 Goal and scope definition (ISO 14040)
2.2 Life cycle inventory (LCI) (ISO 14041)

2.3 Life cycle impact assessment (LCIA) (ISO 14042)

2.4 Life cycle assessment and interpretation (LCAI) (ISO 14043)

Goal and Scope Definition: In goal definition and scoping, the use of the results is identified, the scope of the study is stated, the functional unit is defined and a strategy and procedures for data collection and data quality assurance are established.

Objectives: The objective of this research is to get a clear picture of impact potential which produced from potable water production where two phases were involved namely production stage and construction stage using LCIA method that is Ecopoints method. This research will identify which impact more outstanding by comparing them using normalization and weighting procedures so that suggestions to reduce the impact can be made.

Functional Unit: Functional unit is quantified performance of a product system for use as a reference unit in a life cycle assessment study [15]. A constant value must be 
created to make the comparison [16]. Functional unit for this study is the production of $1 \mathrm{~m}^{3}$ of treated water a day that fits the standard quality set by Ministry of Health, Malaysia.

Description of the System under Study: There are two stages which became the basis of comparison for this study namely production construction stage.

Production Stage: Raw water extracted from rivers will go through the following process in the water treatment plant [17]:

Screening: To remove floating big sized rubbish on the surface of the water.

Coagulation and Flocculation: Coagulation process is a process of forming particles called floc. Coagulant need to be added to form floc. The coagulants that are normally use includes Aluminium Sulphate, Ferric Sulphate and Ferric Chloride. Tiny flocs will in turn attract each other while at the same time pulling the dissolved organic material and particulate to combine, forming a big flocculant particle. This process is called flocculation.

Settling: Aggregated flocs settle on the base of the settler. The accumulation of floc settlement is called settling sludge.

Filtration: Part of the suspended matter that did not settle goes through filtration. Water passing through filtration consisting of sand layers and activated carbon or anthracite coal.

Disinfection: Process is needed to eliminate the pathogen organisms that remain after filtration. Among the chemicals used for the disinfection are chlorine, chloramines, chlorine dioxide, ozone and UV radiation.

Construction Stage: Main building materials used for water treatment plant building are concrete and steel. Concrete is a type of composite material which is usually used in construction. It is a combination of the following:

- Cement

- $\quad$ Fine aggregate / sand

- Coarse aggregate

- Water
The quality of the concrete which is produced depends on the quality of the raw materials that is being used such as cement, coarse aggregate and water, rate of mixing, the method of mixing, transportation and compression methods. If the raw materials used are not of quality, the concrete produced will have low quality and causes the concrete to be weak and doesn't fulfill the fixed specifications. So, concrete technology warrants that all the materials that will be used should be tested first and certified through fixed standardizations. before being used in construction works.

Steel increases the tensile strength of the concrete structure. Reinforcement steel functions to increase the tensility strength of the concrete structure. Types of reinforcement steel that are used are as follows:

- Mild steel reinforcement /mild steel

- Reinforcement steel with high tensility

- $\quad$ Fabric steel (fabric)

The steel that are provided are $12 \mathrm{~m}$ long, with diameter of $6 \mathrm{~mm}, 8 \mathrm{~mm}, 10 \mathrm{~mm}, 12 \mathrm{~mm}, 16 \mathrm{~mm}, 20 \mathrm{~mm}, 22 \mathrm{~mm}$, $25 \mathrm{~mm}$ dan $32 \mathrm{~mm}$. The reinforcement steel will be cut and moulded according to the concrete structure design. Reinforcement steel with high tensility is used as the backbone concrete structure because it has high strength. Mild steel reinforcement is usually in fixation for reinforcement steel with high tensility where high tensility is not needed. High tension where high force not needed. Fabric steel (fabric) is used in a wide concrete surface area such as floor, it comes in sizes of $2.4 \mathrm{~m} \mathrm{x} 1.8 \mathrm{~m}$ with steel diameter $4 \mathrm{~mm}$ to $12 \mathrm{~mm}$ and distance between each steel rods are different based on types of fabric. Reinforcement steed that is used should be free from any dirt and rust, so it has to be protected from water and humidity.

Life Cycle Inventory (LCI): The inventory of the studied LCA system includes information on the input and output (environmental exchanges) for all the process within the boundaries of the product system (Figure 2). The inventory is a long list of material and energy requirements, products and co-products as well as wastes. This list is referred to as the material and energy balance, the inventory table, or the eco-balance of the product [18]. This LCA study is a streamlined LCA where background data for electricity, chemicals and transport using database contained in the Jemaipro and Simapro 7 software. Foreground data collected from the treatment plant are: (Table 1). 


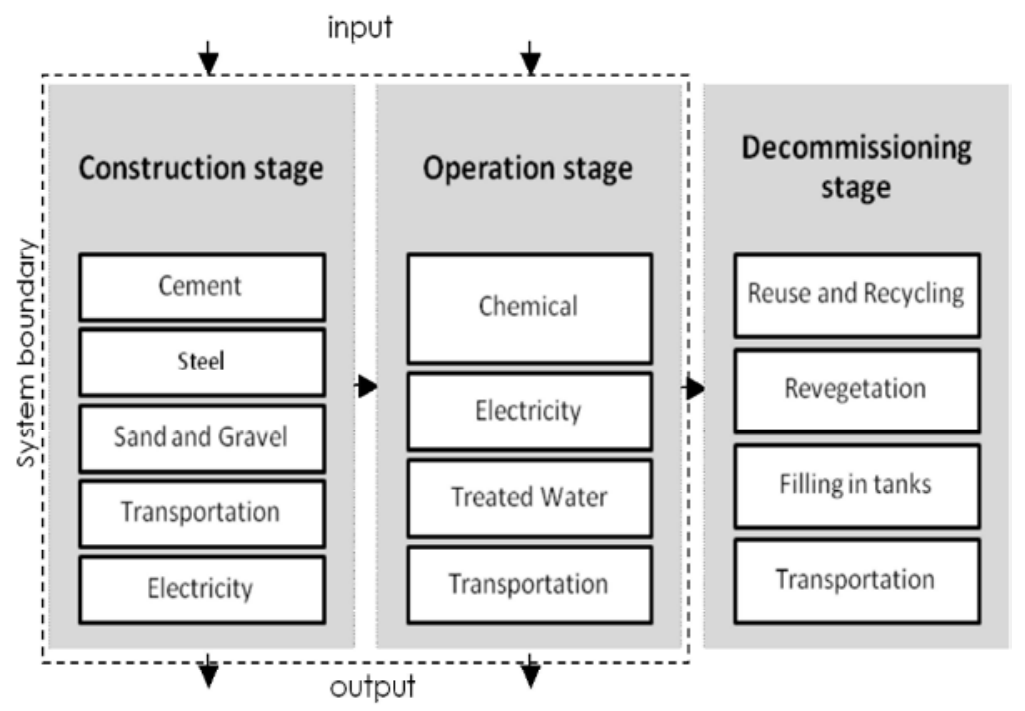

Fig. 2: System Boundary of Potable Water Treatment Plant

Table 1: Foreground data for construction stage and production stage

\begin{tabular}{|c|c|c|c|}
\hline \multicolumn{2}{|l|}{ Construction Stage } & \multicolumn{2}{|l|}{ Production Stage } \\
\hline Steel (kg) & 8.78 & Alum $(\mathrm{kg})$ & 22.55 \\
\hline Cement (kg) & 30.72 & Chlorine (kg) & 3.65 \\
\hline Gravel (kg) & 70.72 & PAC (kg) & 16.85 \\
\hline Sand (kg) & 47.15 & Lime (kg) & 11.12 \\
\hline Electricity (kwh) & 0.09 & Electricity (kwh) & 397.28 \\
\hline Tap water (liter) & 477.26 & & \\
\hline
\end{tabular}

- Electricity usage and

- Chemicals for water treatment such as Aluminium sulphate (alum), Polyaluminium chloride (PAC), Chlorine and Calcium hydroxide (lime)

- Building material such as steel, gravel, sand and cement

Filtration material (activated carbon and anthracite) and coagulant (ferrochloride) are not included in this study because all the water treatment plants in Malaysia are not using all these materials.

Background data for all building materials and chemicals obtained from Japan Environmental Management Association for Industry (JEMAI) - PAC, BUWAL 250 - chlorine, alum and Electricity, ETH-ESU 98 lime, LCA Food DK - tap water and IDEMAT 2001 cement, steel, sand and gravel.

Life Cycle Impact Assessment (LCIA): LCIA for this study uses The Ecological Scarcity method or also known as Swiss Ecopoints. This method enables to do a comparison between weighting and aggregation among environmental interventions or known as eco-factor.
This method provides the different weighting factors to emission/release into the top-soil, groundwater, water, air and energy sources. Eco-factors are based on annual actual flows or current flow and annual flow that consider as critical flows at certain location such as region or country. [19].

This eco-factor made based on Switzerland, where current flows are taken from the latest statistic data whilst critical flows had being deduced from scientific objective that is fixed by Swiss environmental policy. This method is also expanded to not only in Switzerland but in several countries like Japan and Belgium.

This method is developed using the top-down principles and assumption from environmental policy framework. It is used as a reference framework for improvement and optimization product or processes. Various damages on ecosystem quality and human health are considered into target setting process for general environmental policy. Furthermore, this policy becomes a basis to the critical flows. The implicit weighting also accepted as various objectives of environmental policy. The Eco-points method contains the common characterization and classification approach such as 
climate change, ozone depletion and acidification. The other interventions are evaluated individually, for example various heavy metal and also by group like pesticides or NM-VOC (non-methane volatile organic compounds).

This approach was built to make as a standard for environmental assessment to all process or product. It is also used as an element in the environmental management system (EMS) of company. This development started in 1997 (first version) and followed by 2005 (second version) which is considering data for 2004 [19-21].

Generally there are 3 steps in LCIA:

2.3.1 Classification and Characterization

2.3.2 Normalization and

2.3.3 Weighting

Classification and Characterization: Classification is an inventory collection process from life cycle to several impact categories [22], while characterization according to
[23], is a type of summation of Life Cycle Inventory for every element under same impact category. The summation of every element using characterization factor and summation value then recognized as category indicator [24]. In [25], category indicator of Life Cycle impact category indicator can be defined as a value that indicates each impact category. Curran [26] suggested that the equation for category indicator is as below and the relationship between impact categories and characterization factor.

\section{Inventory Data $\mathrm{x}$ Characterization Factor $=$ Category Indicator}

Characterization for Construction Stage: There are 30 main impact categories in Ecopoints method. Those categories are shown in Table 2. Analysis indicate that steel production contributes higher impact to most impact categories listed. Steel production contributed $60-90 \%$ compared to other building materials and electricity.

Table 2: Contribution from building materials to a few impact categories

\begin{tabular}{|c|c|c|c|c|c|c|c|c|}
\hline \multicolumn{2}{|c|}{ Impact category } & \multirow{2}{*}{$\begin{array}{ll} & \text { Unit } \\
\mathrm{g} & \end{array}$} & \multirow{2}{*}{$\begin{array}{l}\text { Cement } \\
31.01129\end{array}$} & \multirow{2}{*}{$\begin{array}{c}\text { Gravel } \\
7.229588\end{array}$} & \multirow{2}{*}{$\frac{\text { Sand }}{4.820066}$} & \multirow{2}{*}{$\begin{array}{c}\text { Steel } \\
535.6428\end{array}$} & \multirow{2}{*}{$\begin{array}{c}\text { Tap water } \\
0.352873\end{array}$} & \multirow{2}{*}{$\begin{array}{l}\text { Electricity } \\
0.1341\end{array}$} \\
\hline 1) & NOx & & & & & & & \\
\hline 2) & $\mathrm{SOx}$ & g SO2 eq. & 16.62977 & 1.693939 & 1.129372 & 506.3258 & 1.361048 & 0.023907 \\
\hline 3) & NMVOC & g & 1.536866 & 0.935535 & 0.623734 & 105.3366 & 0.246374 & 0.011633 \\
\hline 4) & $\mathrm{NH} 3$ & $\mathrm{~g}$ & 0.006074 & 0.000702 & 0.000468 & 0.013451 & $8.08 \mathrm{E}-05$ & $1.75 \mathrm{E}-05$ \\
\hline 5) & Dust PM10 & $\mathrm{g}$ & 169.4047 & 0.019043 & 0.012697 & 44.2025 & 0.061336 & 0 \\
\hline 6) & $\mathrm{CO} 2$ & $\mathrm{~g} \mathrm{CO} 2$ eq. & 11511.31 & 621.6569 & 414.4672 & 104252.9 & 184.9342 & 72.63223 \\
\hline 7) & Ozone layer & g CFC-11 & 0.000123 & $1.42 \mathrm{E}-05$ & $9.49 \mathrm{E}-06$ & 0.000273 & 0.000115 & $1.33 \mathrm{E}-07$ \\
\hline 8) & $\mathrm{Pb}$ (air) & $\mathrm{g}$ & 0.000274 & $3.17 \mathrm{E}-05$ & $2.11 \mathrm{E}-05$ & 0.790806 & $7.06 \mathrm{E}-05$ & $3.25 \mathrm{E}-07$ \\
\hline 9) & Cd (air) & $\mathrm{g}$ & $1.37 \mathrm{E}-05$ & $1.58 \mathrm{E}-06$ & $1.05 \mathrm{E}-06$ & 0.021981 & $3.41 \mathrm{E}-05$ & $2.06 \mathrm{E}-08$ \\
\hline 10) & $\mathrm{Zn}$ (air) & $\mathrm{g}$ & 0.000492 & $5.69 \mathrm{E}-05$ & $3.79 \mathrm{E}-05$ & 0.385272 & 0.000103 & $5.24 \mathrm{E}-07$ \\
\hline 11) & Hg (air) & $\mathrm{g}$ & $4.14 \mathrm{E}-05$ & $4.78 \mathrm{E}-06$ & $3.19 \mathrm{E}-06$ & 0.006238 & $1.7 \mathrm{E}-06$ & $1.31 \mathrm{E}-06$ \\
\hline 12) & COD & $\mathrm{g}$ & 1.133609 & 0.131986 & 0.087997 & 2.525249 & 0.092393 & 0.065511 \\
\hline 13) & $\mathrm{P}$ & $\mathrm{g}$ & 0.020954 & 0.002422 & 0.001615 & 0.046403 & 0.000175 & 0.000157 \\
\hline 14) & $\mathrm{N}$ & $\mathrm{g}$ & 0.012976 & 0.001596 & 0.001064 & 0.029553 & 0.002065 & $5.34 \mathrm{E}-05$ \\
\hline 15) & $\mathrm{Cr}$ (water) & $\mathrm{g}$ & 0.010768 & 0.001245 & 0.00083 & 0.032626 & 0.000101 & $8.2 \mathrm{E}-05$ \\
\hline 16) & Zn (water) & $\mathrm{g}$ & 0.010836 & 0.001252 & 0.000835 & 0.120575 & 0.000135 & $8.05 \mathrm{E}-05$ \\
\hline 17) & $\mathrm{Cu}$ (water) & $\mathrm{g}$ & 0.005358 & 0.000619 & 0.000413 & 0.025914 & $4.72 \mathrm{E}-05$ & $4.01 \mathrm{E}-05$ \\
\hline 18) & Cd (water) & $\mathrm{g}$ & $5.83 \mathrm{E}-05$ & $6.74 \mathrm{E}-06$ & 4.49E-06 & 0.000744 & $3.44 \mathrm{E}-06$ & 4.04E-07 \\
\hline 19) & Hg (water) & $\mathrm{g}$ & $2.5 \mathrm{E}-06$ & $2.89 \mathrm{E}-07$ & $1.93 \mathrm{E}-07$ & 0.000532 & $1.41 \mathrm{E}-07$ & $7.04 \mathrm{E}-08$ \\
\hline 20) & $\mathrm{Pb}$ (water) & $\mathrm{g}$ & 0.00555 & 0.000641 & 0.000428 & 0.02985 & $6.05 \mathrm{E}-05$ & $4.03 \mathrm{E}-05$ \\
\hline 21) & $\mathrm{Ni}$ (water) & g & 0.00541 & 0.000625 & 0.000417 & 0.011981 & $4.79 \mathrm{E}-05$ & $4.03 \mathrm{E}-08$ \\
\hline 22) & AOX (water) & g Cl- & $9.05 \mathrm{E}-06$ & $1.05 \mathrm{E}-06$ & $6.97 \mathrm{E}-07$ & $2 \mathrm{E}-05$ & $5.34 \mathrm{E}-06$ & $1.06 \mathrm{E}-08$ \\
\hline 23) & Nitrate (soil) & g & 0 & 0 & 0 & 0 & 0 & 0 \\
\hline 24) & Metals (soil) & $\mathrm{g} \mathrm{Cd} \mathrm{eq}$ & 0 & 0 & 0 & 0 & $3.01 \mathrm{E}-07$ & 0 \\
\hline 25) & Pesticide soil & $\mathrm{g}$ & 0 & 0 & 0 & 0 & 0 & 0 \\
\hline 26) & Waste & $\mathrm{g}$ & 269.7103 & 34.00123 & 21.08485 & 1003.693 & 0 & 0 \\
\hline 27) & Waste (special) & g & 0 & 0 & 0 & 0 & 0 & 0 \\
\hline 28) & LMRAD & $\mathrm{cm} 3$ & 0.166671 & 0.019264 & 0.012844 & 0.369088 & 0 & 0 \\
\hline 29) & HRAD & $\mathrm{cm} 3$ & 0.00074 & $8.55 \mathrm{E}-05$ & $5.7 \mathrm{E}-05$ & 0.001639 & 0 & 0 \\
\hline 30) & Energy & MJ LHV & 140.4258 & 8.063551 & 5.376081 & 1856.551 & 2.422348 & 0.85417 \\
\hline
\end{tabular}


World Appl. Sci. J., 11 (9): 1077-1088, 2010

Table 3: Chemical substances and electricity contribution to a few impact category

\begin{tabular}{|c|c|c|c|c|c|c|c|}
\hline \multicolumn{2}{|c|}{ Impact category } & \multirow{2}{*}{$\begin{array}{ll} & \text { Unit } \\
\mathrm{g} & \end{array}$} & \multirow{2}{*}{$\begin{array}{l}\text { Chlorine } \\
25.55\end{array}$} & \multirow{2}{*}{$\begin{array}{c}\text { Alum } \\
24.80052\end{array}$} & \multirow{2}{*}{$\frac{\text { PAC }}{151650.3}$} & \multirow{2}{*}{$\begin{array}{c}\text { Lime } \\
8.16887\end{array}$} & \multirow{2}{*}{$\begin{array}{l}\text { Electricity } \\
591.9472\end{array}$} \\
\hline 1) & NOx & & & & & & \\
\hline 2) & SOx & g SO2 eq. & 44.43656 & 313.2135 & 151650 & 17.64707 & 105.5292 \\
\hline 3) & NMVOC & $\mathrm{g}$ & 13.53245 & 5.656589 & 0.021795 & 1.945578 & 51.35229 \\
\hline 4) & NH3 & $\mathrm{g}$ & 0.006205 & 0.013886 & $3.27 \mathrm{E}-05$ & 0.006184 & 0.077072 \\
\hline 5) & Dust PM10 & $\mathrm{g}$ & 0 & 0 & $6.23 \mathrm{E}-06$ & 0.234104 & 0 \\
\hline 6) & $\mathrm{CO} 2$ & g CO2 eq. & 4577.91 & 6200.96 & 371.8875 & 11644.08 & 320614.8 \\
\hline 7) & Ozone layer & g CFC-11 & 0.000584 & 0.001588 & $2.54 \mathrm{E}-07$ & 0.000588 & 0.000589 \\
\hline 8) & $\mathrm{Pb}$ (air) & $\mathrm{g}$ & 0.000475 & 0.001687 & $6.09 \mathrm{E}-07$ & 0.002272 & 0.001434 \\
\hline 9) & Cd (air) & $\mathrm{g}$ & 4.75E-05 & 0.000466 & $3.86 \mathrm{E}-08$ & $6.72 \mathrm{E}-05$ & $9.1 \mathrm{E}-05$ \\
\hline 10) & Zn (air) & $\mathrm{g}$ & 0.000767 & 0.002209 & $9.84 \mathrm{E}-07$ & 0.004665 & 0.002312 \\
\hline 11) & Hg (air) & $\mathrm{g}$ & $7.66 \mathrm{E}-05$ & 0.000141 & $2.46 \mathrm{E}-06$ & $9.97 \mathrm{E}-05$ & 0.0058 \\
\hline 12) & COD & $\mathrm{g}$ & 1.476425 & 1.485189 & 0.122654 & 1.237757 & 289.1797 \\
\hline 13) & $\mathrm{P}$ & $\mathrm{g}$ & 0.023871 & 0.04011 & 0.000294 & 0.044135 & 0.692423 \\
\hline 14) & $\mathrm{N}$ & $\mathrm{g}$ & 0.04653 & 0.094736 & 0.0001 & 0.01627 & 0.235602 \\
\hline 15) & $\mathrm{Cr}$ (water) & $\mathrm{g}$ & 0.01241 & 0.020835 & 0.000154 & 0.022634 & 0.361922 \\
\hline 16) & Zn (water) & $\mathrm{g}$ & 0.01241 & 0.021032 & 0.000151 & 0.023084 & 0.355168 \\
\hline 17) & $\mathrm{Cu}$ (water) & $\mathrm{g}$ & 0.006205 & 0.010305 & $7.5 \mathrm{E}-05$ & 0.011266 & 0.17679 \\
\hline 18) & Cd (water) & $\mathrm{g}$ & $8.03 \mathrm{E}-05$ & 0.000152 & $7.57 \mathrm{E}-07$ & 0.000164 & 0.001784 \\
\hline 19) & $\mathrm{Hg}$ (water) & $\mathrm{g}$ & $2.59 \mathrm{E}-06$ & $3.85 \mathrm{E}-06$ & $1.32 \mathrm{E}-07$ & $2.77 \mathrm{E}-06$ & 0.000311 \\
\hline 20) & $\mathrm{Pb}$ (water) & $\mathrm{g}$ & 0.0073 & 0.012594 & $7.55 \mathrm{E}-05$ & 0.01163 & 0.177981 \\
\hline 21) & $\mathrm{Ni}$ (water) & $\mathrm{g}$ & 0.006205 & 0.010074 & 7.64E-08 & 0.011362 & 0.000178 \\
\hline 22) & AOX (water) & g Cl- & $4.38 \mathrm{E}-05$ & 0.000115 & $2.01 \mathrm{E}-08$ & $2.29 \mathrm{E}-05$ & $4.69 \mathrm{E}-05$ \\
\hline 23) & Nitrate (soil) & $\mathrm{g}$ & 0 & 0 & 0 & 0 & 0 \\
\hline 24) & Metals (soil) & $\mathrm{g} \mathrm{Cd} \mathrm{eq}$ & 0 & 0 & $1.01 \mathrm{E}-11$ & $2.68 \mathrm{E}-06$ & 0 \\
\hline 25) & Pesticide soil & g act.subst. & 0 & 0 & 0 & 0 & 0 \\
\hline 26) & Waste & $\mathrm{g}$ & 362.445 & 0 & 0 & 0 & 0 \\
\hline 27) & Waste (special) & $\mathrm{g}$ & 0 & 0 & 0 & 0 & 0 \\
\hline 28) & LMRAD & $\mathrm{cm} 3$ & 0 & 0 & 0 & 0 & 0 \\
\hline 29) & HRAD & $\mathrm{cm} 3$ & 0 & 0 & 0 & 0 & 0 \\
\hline 30) & Energy & MJ LHV & 74.08332 & 141.606 & 3.534974 & 52.947 & 3770.495 \\
\hline
\end{tabular}

Steel production contribute around $90 \%$ to $\mathrm{Pb}$ (air), $\mathrm{Cd}$ (air), Zn (air), Hg (air), NOx, Sox, NMVOC, Cd (water) and Energy. Steel production contributes to over $60 \%$ are $\mathrm{NH}$, Ozone, $\mathrm{COD}, \mathrm{P}, \mathrm{N}, \mathrm{Cr}$ (water), $\mathrm{Zn}$ (water), $\mathrm{Pb}$ (water), $\mathrm{Ni}$ (water), HOX (water), Waste, LMRD and HRAD.

Out of all impact categories listed showed that cement contributes over $20 \%$ and the remaining contributes by other substances and electricity. There are three impact categories which are not contribute by construction materials and electricity such as Nitrate, waste (special) and pesticide. Furthermore 100\% metal impact category (soil) contributed from tap water. Tap water also contributed more than $20 \%$ for ozone layer impact categories. Overall, Gravel and sand contributed the least of all categories that is less than $5 \%$.

\subsubsection{Characterization for Production Stage}

On the whole, most of the impact categories are from the electricity usage. The contribution are more than $60 \%$ to 14 impact categories came from the electricity usage. The impacts are NMVOC, NH3, CO2, $\mathrm{P}, \mathrm{N}, \mathrm{Cr}$ (water),
$\mathrm{Zn}$ (water), $\mathrm{Cu}$ (water), $\mathrm{Cd}$ (water), $\mathrm{Hg}$ (water), $\mathrm{Pb}$ (water) and Energy. Other than that, there are a few Chemicals substances contributed nearly $100 \%$ for example PAC contributed to NOx and Sox, Lime contributed to Dust PM10 and Metals and Chlorine contributed to waste.

Furthermore, Alum also contributes between 25\% $70 \%$ to several impact categories such as Ozone, $\mathrm{Pb}$ (water), Cd (water), $\mathrm{Zn}$ (water), N, Ni (water) and AOX (water). Table 2 showed the contribution from chemicals that gave impact to environment especially from electricity generation process (coloured column).

Normalization: According to [27] normalization enable the impact categories to be distinguished. There are two reasons why normalization is conducted, first is to identify the impact categories that should give mere attention and second, to obtain the magnitude of environmental degradation produced during the life cycle of the product [28]. Normalization is determined based on the formula shown below [13]: 


$$
N_{k}=S_{k} / R_{k} \text { where; }
$$

$\mathrm{k}=$ Impact category

$\mathrm{N}=$ Normalisation indicator

$\mathrm{S}=$ Category indicator (from characterization)

$\mathrm{R}=$ Reference value

Normalization for Construction Stage: From Figure 3 indicate that $\mathrm{CO} 2$ impact category more outstanding compared to other impact categories. Steel production found to be the biggest contributor where $\mathrm{CO} 2$ contributed as much as $89 \%$ (104252.9 unit) compared to the other building materials (cement $-9.8 \%$, Gravel $0.5 \%$, Sand $-0.4 \%$, tap water $-0.2 \%$ ) and Electricity $(0.06 \%)$.

Normalization for Production stage: In production stage, normalization showed that NOx, SOx and $\mathrm{CO} 2$ impact categories are more outstanding compared to other impact categories (Figure 4). For second place, Nox and Sox, almost $100 \%$ contributed from PAC are NOx $-99.6 \%$ and Sox $-99.7 \%$. Meanwhile CO2 is more contributed by using electricity energy (93.4\%) compared to others (PAC $-0.1 \%$, Chlorine $-1.3 \%$, Alum $-1.81 \%$ and Lime $-3.4 \%$ ).

Weighting: Weighting is conducted by multiplying category indicator with weighting factor and summed to get the score [23]. Because of this method is not damage oriented, therefore the weighting value is not summed (summed is based to the same category) to get single score for comparison purpose with other damage categories. Weighting is determined based on formula as in [13]:

$$
\mathrm{EI}=? V_{k} N_{k} \text { OR EI }=\Sigma V_{k} S_{k} \text { where; }
$$

$\mathrm{k}=$ Impact category

$\mathrm{EI}=\quad$ Indicator to all environmental impact

$\mathrm{V}=$ weighting factor

$\mathrm{N}=$ Normalisation indicator

$\mathrm{S}=$ Category indicator (from characterization)

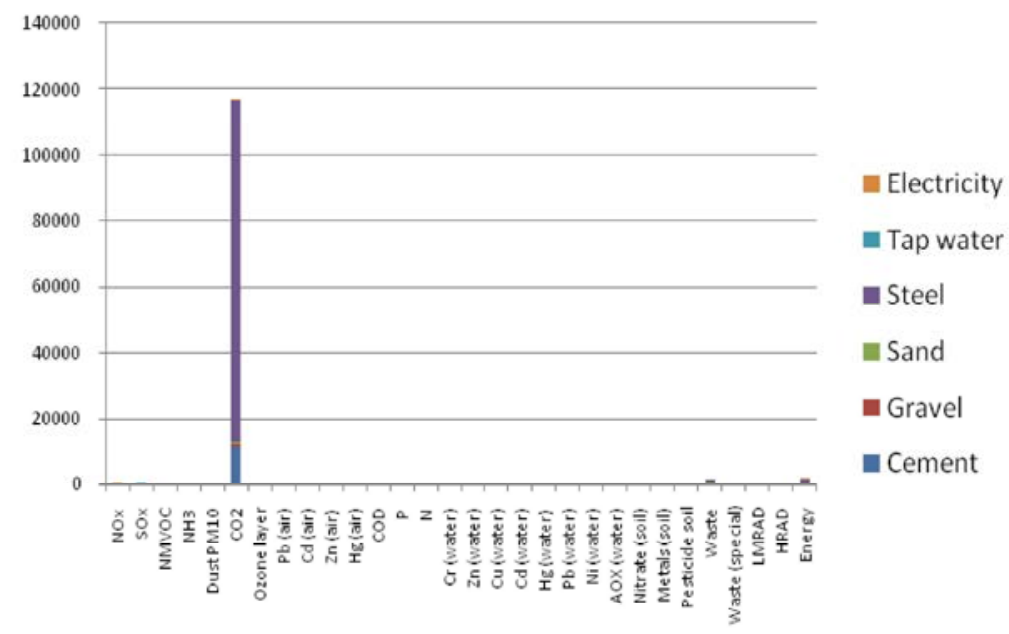

Fig. 3: Normalization for impact categories from construction substances and electricity.

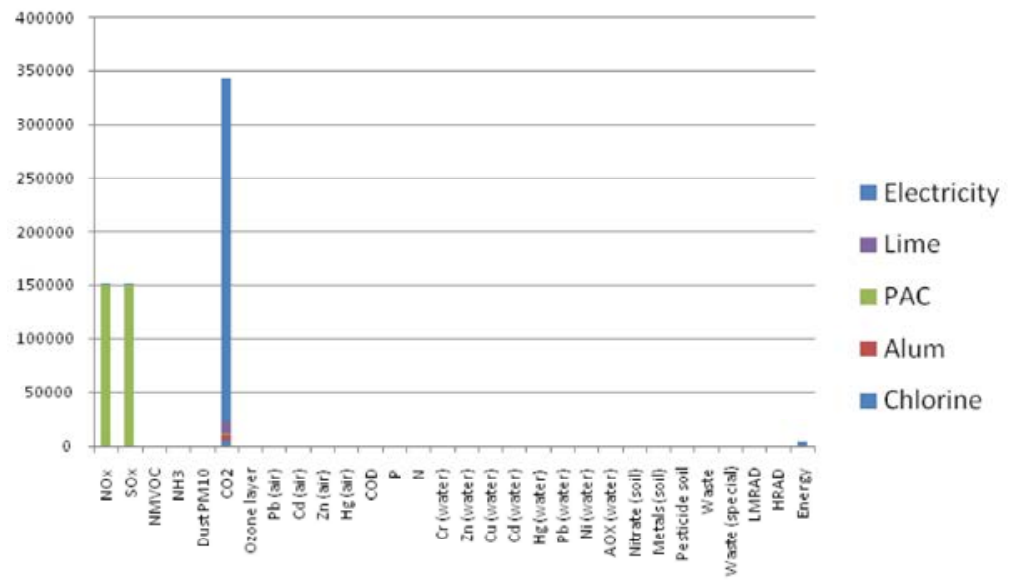

Fig. 4: Normalization graph for impact category contributed from chemical substances and electricity. 


\begin{tabular}{|c|c|c|c|c|c|c|c|}
\hline Emission to air & Eco-points/g & Emission to surface water & Eco-points/g & Emission to top-soil & Eco-points/g & Wastes & Eco-points/g \\
\hline Nox & 67 & COD & 5.9 & $\mathrm{~Pb}$ & 2900 & Waste to inert, & 0.5 \\
\hline $\mathrm{SO} 2$ & 53 & DOC & 18 & $\mathrm{Cu}$ & 1900 & sanitary, & \\
\hline NMVOC & 32 & TOC & 18 & $\mathrm{Cd}$ & 120000 & residual & \\
\hline NH3 & 63 & Phosphorus (P) & 2000 & $\mathrm{Zn}$ & 520 & material & \\
\hline $\mathrm{Hcl}$ & 47 & $\mathrm{~N}$ total & 69 & $\mathrm{Ni}$ & 1900 & landfills & \\
\hline $\mathrm{HF}$ & 85 & NH4+ & 54 & $\mathrm{Cr}$ & 1300 & Waste to & 24 \\
\hline PM10 & 110 & NO3- & 16 & Co & 3800 & underground & \\
\hline $\mathrm{CO} 2$ & 0.2 & $\mathrm{Cr}$ & 660 & $\mathrm{Hg}$ & 120000 & deposit & \\
\hline $\mathrm{CH} 4$ & 4.2 & $\mathrm{Zn}$ & 210 & $\mathrm{Th}$ & 96000 & Radioactive wastes & \\
\hline $\mathrm{N} 2 \mathrm{O}$ & 62 & $\mathrm{Cu}$ & 1200 & Mo & 19000 & Nuclear waste & 3300 \\
\hline R11eq & 2000 & $\mathrm{Cd}$ & 11000 & Pesticides & 800 & type B & \\
\hline $\mathrm{Pb}$ & 2900 & $\mathrm{Kg}$ & 240000 & & & Nuclear waste & 46000 \\
\hline $\mathrm{Cd}$ & 120000 & $\mathrm{~Pb}$ & 150 & & & type $\mathrm{C}$ & \\
\hline $\mathrm{Zn}$ & 520 & $\mathrm{Ni}$ & 190 & & & & \\
\hline \multirow[t]{3}{*}{$\mathrm{Hg}$} & 120000 & $\mathrm{AOX}$ & 330 & & & 3300 & \\
\hline & & Emission to groundwater & & & & & \\
\hline & & nitrate & 27 & & & & \\
\hline
\end{tabular}

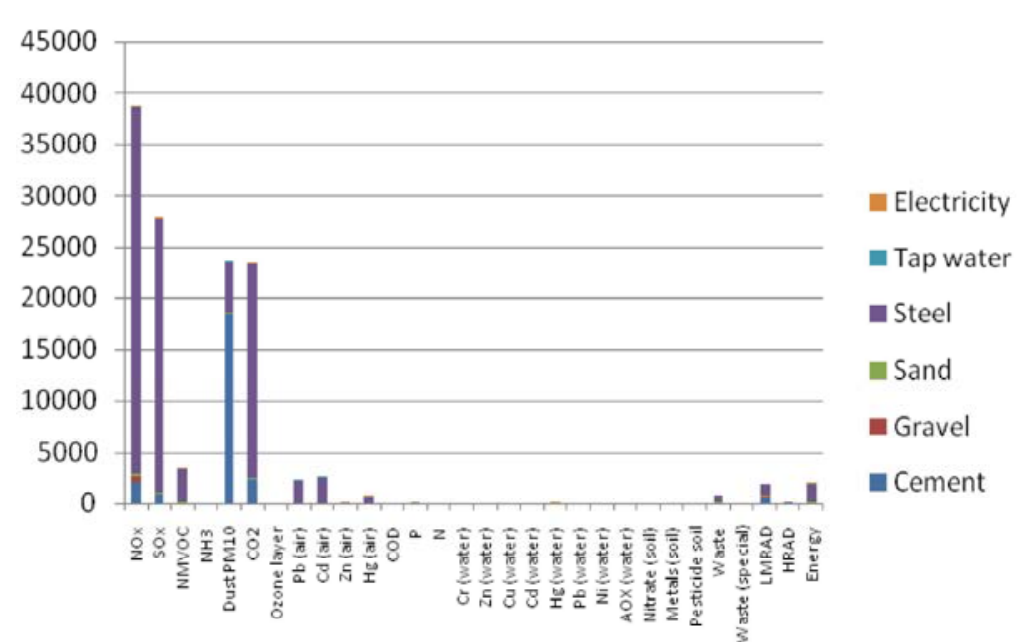

Fig. 5: Weighting for impact category contribution from construction substances and electricity.

Weighting factors used in Ecopoints method as reported in Brand et al. [19] showed in Table 4.

Weighting for Construction Stage: There are four outstanding impact categories compared to others namely Nox, Sox, CO2 and Dust PM10 (Figure 5). NOx and SOx contributed as much as $92.5 \%$ dan $96.05 \%$ respectively by steel production. NOx is the biggest impact followed by SOx, CO2 dan Dust PM10. CO2 contributed higher by steel production $(89.1 \%)$ followed by cement production (9.8\%). While Dust PM10 contributed higher by cement production (79.2\%) followed by steel production $(20.7 \%)$.

Weighting for Production Stage: Similar to construction stage, NOx and SOx are the most outstanding but at the production stage only these two impacts are obviously outstanding compared to others (Figure 6). Both impacts nearly $100 \%$ contributed by PAC (Nox $-99.6 \%$ and $\mathrm{SOx}-99.7 \%$ ).

Life Cycle Assessment and Interpretation (LCAI): The analysis indicate that production stage create more impact than construction stage. The impact contributed from production stage are NOx and SOx. The same goes to construction stage where NOx and SOx are also the highest impact compared to two other main impacts namely Dust PM10 and CO2. NOx and SOx contributed by PAC while NOx and SOx in constrction stage contributed the highest by steel processing. Network analysis had been carried out to identify the processes that contribute to NOx and SOx from steel processing. From the analysis (Figure 7 and Figure 8) showed both impacts contributed by transports using fossil fuel. 
World Appl. Sci. J., 11 (9): 1077-1088, 2010

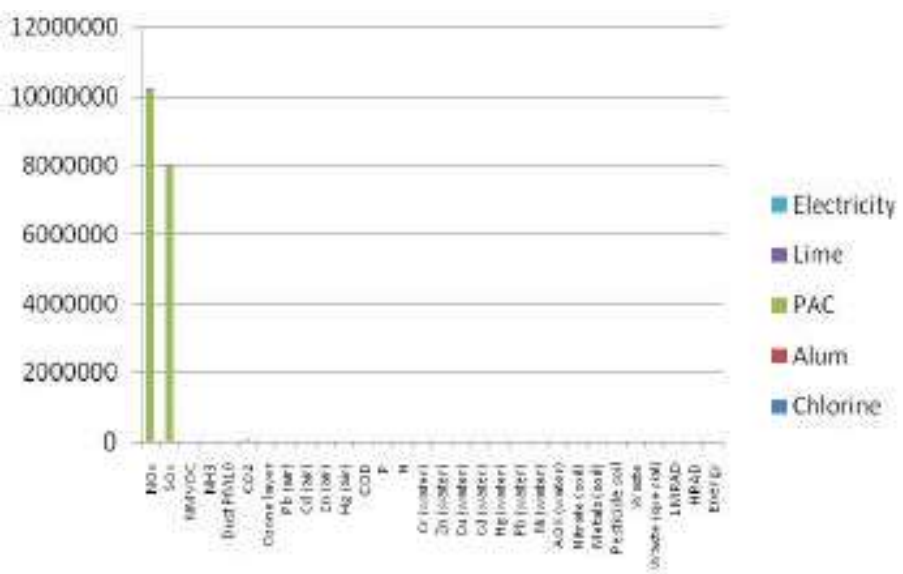

Fig. 6: Weighting for impact category contribute from construction substances and electricity

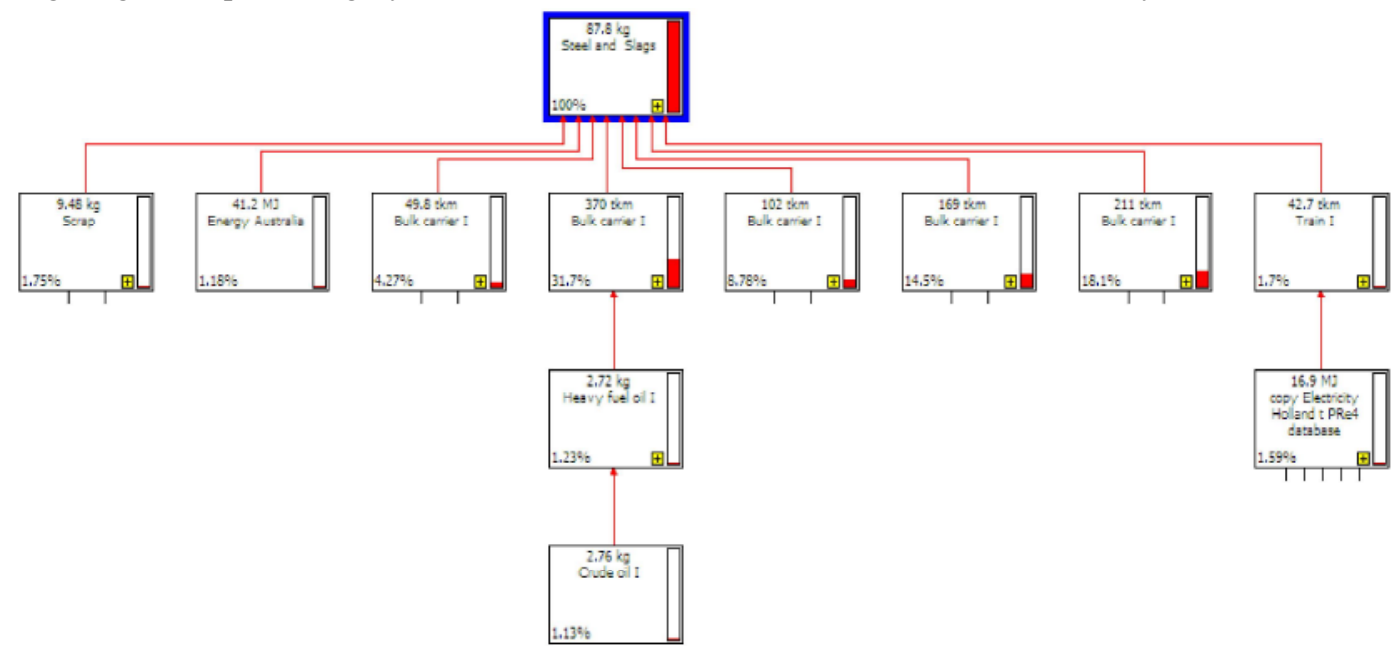

Fig. 7: Network for processes in producing steel. Coloured bar for each box showed NOx contribution in each process.

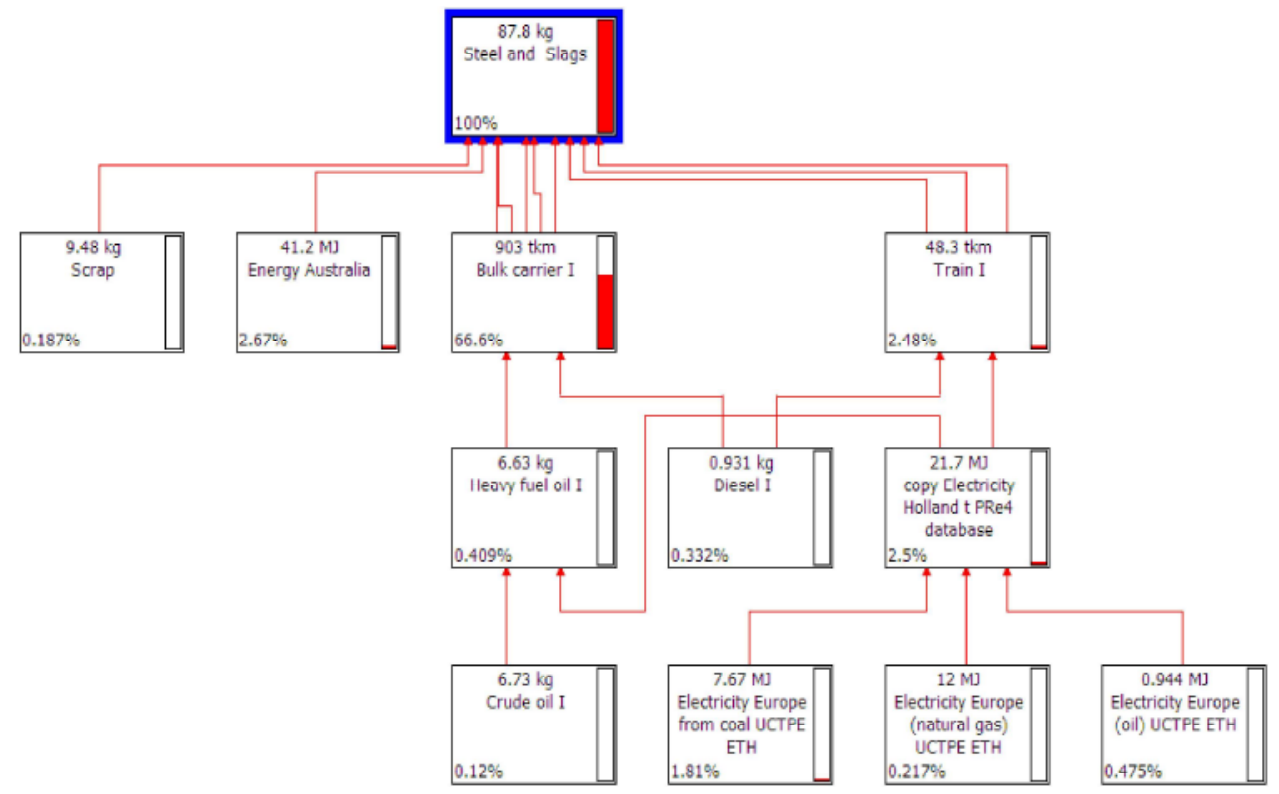

Fig. 8: Network processes in producing steel. Coloured bar for each box showed SOx contribution in each process. 


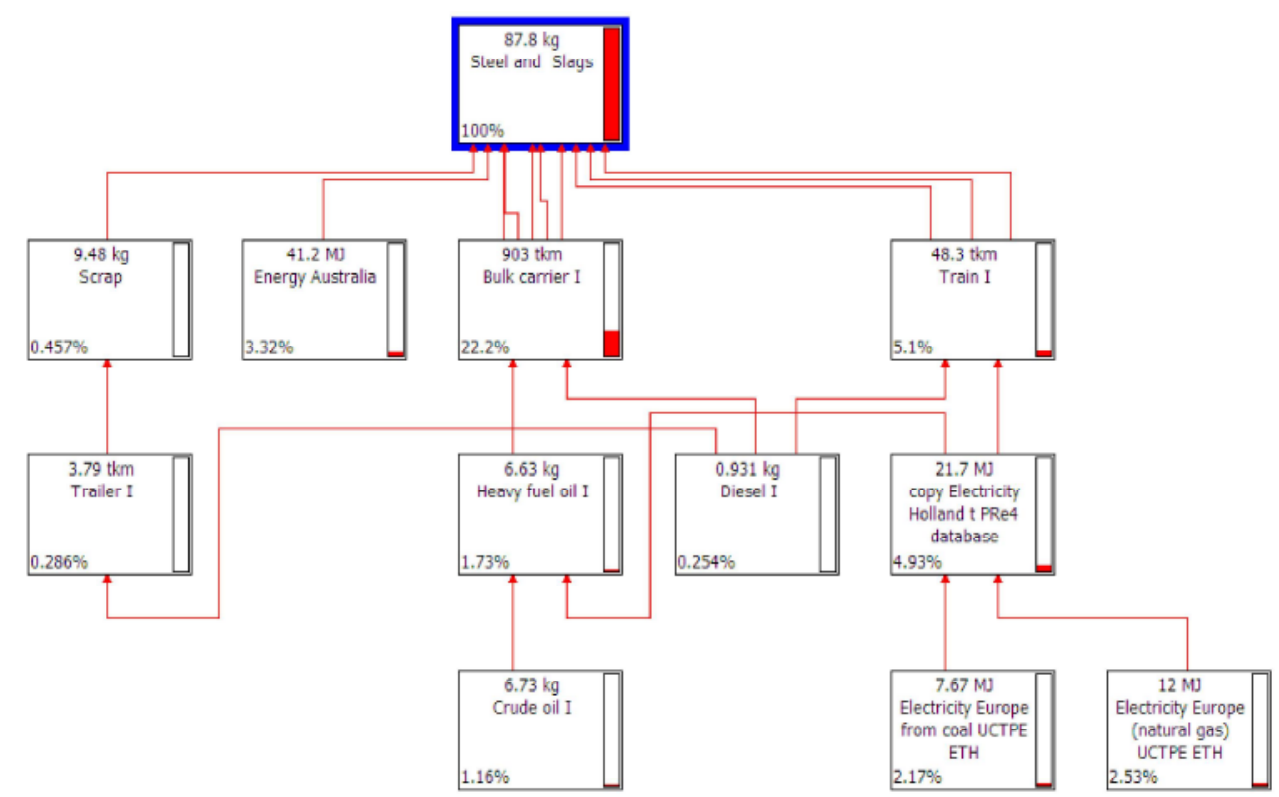

Fig. 9: Network for processes in producing steel. Coloured bar for each box showed $\mathrm{CO} 2$ contribution in each process.

Meanwhile in construction stage, producing steel process contributed more $\mathrm{CO} 2$. Network analysis (Figure 9) discovered that $\mathrm{CO} 2$ released by transport using fossil fuel.

\section{CONCLUSION AND RECOMMENDATION}

The weaknesses had been identified at production stage are NOx and SOx released form PAC which been used as coagulant in potable water treatment. Previous research [29, 30] discovered that using Alum is better because it does not release NOx and SOx. Meanwhile in construction stage, both substances are release from steel production.

Steel is the basic component in water treatment plant construction. Now, the latest idea is to replace the reinforcement steel with fibre reinforced plastics (FRPs). These materials, which consist of glass, carbon or aramid fibres set in a suitable resin to form a rod or grid, are well accepted in the aerospace and automotive industries and should provide highly durable concrete reinforcement [31]. Before we can declare this alternative is nature friendly or equal quality to steel, it has to go through LCA analysis process.

As for the $\mathrm{CO} 2$ emission, most of the $\mathrm{CO} 2$ released were contributed by transport and electricity energy. Previous research showed a comparison among a few types of alternatives generate electricity energy have been conducted and discovered that photovoltaic, hydro and uranium are better than electricity energy using fossil fuel [32].

\section{REFERENCES}

\section{Missing}

2. Jolliet, O., R. A.Mueller-Wenk, C. Peña, et al. 2003. Life Cycle Impact Assessment Programme of the Life Cycle Initiative. Final report of the LCIA Definition study [Electronic Version]. Retrieved 17 September 2007, from http:// lcinitiative.unep.fr/ includes/ file.asp? site $=$ lcinitandfile=F7BF1ABF-8B98-4A95-9FDE3E32EB7C4EC4

3. Heijungs, R., M. Goedkoop, J. Struijs, S. Effting, M. Sevenster and G. Huppes, 2003. Towards a life cycle impact assessment method which comprises category indicators at the midpoint and the endpoint level. Report of the first project phase Design of the new method [Electronic Version]. Retrieved 7 Mac 2007, from http:// www.leidenuniv.nl/ cml/ssp/ publications/recipe_phase1.pdf

4. Jolliet, O., M. Margni, R. Charles, S. Humbert, J. Payet, G. Rebitzer, et al. 2003. IMPACT 2002+: A New Life Cycle Impact Assessment Methodology. The International J. Life Cycle Assessment, 8(6): 324-330.

5. Jolliet, O., R. Müller-Wenk, J. Bare, A. Brent, M. Goedkoop, R. Heijungs, et al. 2004. The LCIA midpoint-damage framework of the UNEP/SETAC life cycle initiative. The International J. Life Cycle Assessment, 9(6): 394-404. 
6. Ortiz, O., C. Francesc, and G. Sonnemann, 2009. Sustainability in the construction industry: A review of recent developments based on LCA. Construction and Building Materials, 23: 28-39.

7. Sleeswijk, A.W., L.F.C.M. Van Oersc, J.B. Guinée, J. Struijsd and M.A.J. Huijbregtsb, 2008. Normalisation in product life cycle assessment: An LCA of the global and European economic systems in the year 2000. Science of the Total Environment, 390: 227-240.

8. Soares, S.R., L. Toffoletto and L. Deschenes, 2006. Development of weighting factors in the context of LCIA. J. Cleaner Production, 14: 649-660.

9. Bare, J.C., P. Hofstetter, D.W. Pennington and H.A. Udo de Haes, 2000. Life Cycle Impact Assessment Workshop Summary. Midpoints versus Endpoints: The Sacrifices and Benefits. The International J. Life Cycle Assessment, 5(6): 319-326.

10. Dreyer, L.C., A.L. Niemann and M.Z. Hauschild, 2003. Comparison of three different LCIA methods:EDIP97, CML2001 and Eco-indicator 99. Does it matter which one you choose? The International J. Life Cycle Assessment, 8(4): 191-200.

11. Josa, A., A. Aguado, A. Cardim and E. Byars, 2007. Comparative analysis of the life cycle impact assessment of available cement inventories in the EU. Cement and Concrete Res., 37: 781-788.

12. Bare, J.C. and T.P. Gloria, 2008. Environmental impact assessment taxonomy providing comprehensive coverage of midpoints, endpoints, damages and areas of protection. J. Cleaner Production, (16): 1021-1035.

13. Pennington, D.W., J. Potting, G. Finnveden, E. Lindeijer, O. Jolliet, T. Rydberg, et al. 2004. Life cycle assessment part 2: Current impact assessment practice. Environment International, 30: 721-739.

\section{Missing}

15. ISO14000. 2000. Malaysian standards handbook on environmental management: MS ISO 14000 Series 2nd Ed. Shah Alam, Malaysia: SIRIM.

16. Miettinen, P. and R.P. Hamalainen, 1997. How to benefit from decision analysis in environmental life cycle assessment (LCA). European J. Operational Res., 102: 279-294.

17. Sastry, C.A., 1996. Water Treatment Plants. New Delhi: Narosa Publishing House.

18. Guinée, J.B., 2002. Handbook on Life Cycle Assessment: Operational Guide to the ISO Standards: Springer.
19. Brand, G., A. Braunschweig, A. Scheidegger and O. Schwank, 1998. Weighting in Ecobalances with the Ecoscarcity Method - Ecofactors 1997: BUWAL (SAFEL) Environment Series, 297, Bern.

20. Ahbe, S., A. Braunschweig and R. Müller-Wenk, 1990. Methodology for Ecobalances Based on Ecological Optimization,. BUWAL (SAFEL) Environment Series No. 133, Berno. Document Number)

21. Müller-Wenk, R., 1994. The Ecoscarcity Method as a Valuation Instrument within the SETAC-Framework. in: Udo de Haes/ Jensen/ Klöpffer/ Lindfors (Ed.): Integrating Impact Assessment into LCA Brussels: SETAC-Europeo. Document Number)

22. Moberg, Å., G. Finnveden, J. Johansson and P. Lind, 2005. Life cycle assessment of energy from solid waste-part 2: landfilling compared to other treatment methods. J. Cleaner Production, 13: 231-240.

23. Bovea, M.D. and A. Gallardo, 2006. The influence of impact assessment methods on materials selection for eco-design. Materials and Design, 27: 209-215.

24. Ntiamoah, A. and G. Afrane, 2008. Environmental impacts of cocoa production and processing in Ghana: life cycle assessment approach. J. Cleaner Production, 16: 1735-1740.

\section{Missing}

26. ISO 14040:2000. 2005. Environmental managementLife cycle assessment-Principle and framework. Malaysian standards handbook on environmental management: MS ISO 14000 Series 2nd Ed, pgs ii-iii. Shah Alam: SIRIM Berhad.

27. Mangena, S.J. and A.C. Brent, 2006. Application of a Life Cycle Impact Assessment framework to evaluate and compare environmental performances with economic values of supplied coal products. J. Cleaner Production, (14): 1071-1084.

28. Goedkoop, M., A.N. Schryver and M. Oele, 2007. Introduction to LCA with Simapro 7. Amersfoort: PRé Consultants.

29. Amir Hamzah, S., M. Noor Zalina and S. Abdul Halim, (2008a, 10-12 December). Life Cycle Impact Assessment (LCIA) of Potable Water Production in Malaysia: A Comparison between Different River Class. Paper presented at the The Eight Conference on Ecobalance 08, Tokyo Big Sight, Japan. 
30. Amir Hamzah, S., M. Noor Zalina and S. Abdul Halim, 2008b. Life Cycle Impact Assessment (LCIA) of Potable Water Production in Malaysia: A Comparison among Different Technology used in Water Treatment Plant. Paper presented at the International Symposium on Environmental Management 2008: Hazardous-Environmental Management Toward Sustainability, Nakorn Nayok, Thailand.
31. Clarke, J., 1998. Concrete Reinforced with Fibre Reinforced Plastic. Materials World, 6(2): 78-80.

32. Amir Hamzah, S., M. Noor Zalina and S. Abdul Halim, 2009. Life Cycle Assessment (LCA) in Potable Water Production: An analysis of greenhouse gases emission from chemicals and electricity usage in water treatment in Malaysia. Asian J. Water, Environment and Pollution, 6(3): 27-34. 